\title{
Introduction to the IJELLO Special Series of Chais Conference 2009 Best Papers
}

\author{
Yoram Eshet-Alkalai, Avner Caspi, Sigal Eden, \\ Nitza Geri, and Yoav Yair \\ The Open University of Israel \\ Raanana, Israel
}

\section{yorames@openu.ac.il; avnerca@openu.ac.il; sigaled@openu.ac.il; nitzage@openu.ac.il; yoavya@openu.ac.il}

\begin{abstract}
This Interdisciplinary Journal of E-Learning and Learning Objects (IJELLO) inaugural issue of special series is based on selected best papers presented in the Fourth Chais Conference on Instructional Technologies Research 2009: Learning in the Technological Era. The Chais conference 2009 was held at The Open University of Israel campus, Raanana, Israel, on February 18, 2009, and was organized by the Chais Research Center for the Integration of Technology in Education.

This preface presents the Chais research center's mission and activities, describes the Chais Conference's objectives and themes, explains its synergies with IJELLO and the Informing Science Institute, and introduces the papers included in this issue.
\end{abstract}

Keywords: instructional technologies, e-learning, technology integration in education, technology acceptance, human-computer interaction, usability, collaborative learning.

\section{Introduction}

Instructional technologies research is an evolving field that undergoes rapid changes due to the frequent emergence of new technologies. While some technologies are widely used, other applications fail or seem not to fulfill their potential and goals. There are many issues concerning the teaching and learning processes, as well as the cognitive and social processes that take place when utilizing instructional technologies, that should be explored. This young field, which draws on theories from various fields such as psychology, education, design, sociology, information systems and organizational behavior, calls for a further conceptual and theory building research.

The Chais Research Center for the Integration of Technology in Education is a consortium of about 50 instructional technology researchers at the Open University of Israel. The mission of the

Material published as part of this publication, either on-line or in print, is copyrighted by the Informing Science Institute. Permission to make digital or paper copy of part or all of these works for personal or classroom use is granted without fee provided that the copies are not made or distributed for profit or commercial advantage AND that copies 1) bear this notice in full and 2) give the full citation on the first page. It is permissible to abstract these works so long as credit is given. To copy in all other cases or to republish or to post on a server or to redistribute to lists requires specific permission and payment of a fee. Contact Publisher@,InformingScience.org to request redistribution permission.
Chais Research Center is to encourage theoretical and practical research among the Open University faculty, staff, and students, in the area of instructional technologies and their integration into educational systems in general, and at the Open University in particular. The Chais Research Center provides a platform for cooperation among researchers within and outside the Open University, 
who are interested in the study of instructional technologies and their integration. The center promotes understanding of educational technologies by funding research projects and by holding seminars, symposia, conferences, and study groups.

These are some of the fields of research, which the Chais Center is engaged in:

- Studying the theoretical foundations of learning, instructional technology and distance education.

- Incorporating information and communication technologies into the design of instructional systems for distance education and determining how these technologies affect the learning process and leaning achievements.

- Defining and characterizing the variables needed for developing flexible and adaptive computer enhanced instructional strategies that respond to students' individual needs.

- Studying the pedagogical and cognitive contributions of emerging technologies on teaching and learning.

"Learning in the Technological Era" is a series of annual national research conferences on learning technologies initiated by the Chais Center in collaboration with EDEN, The European Distance and E-Learning Network. The conference contributes to the formation of a community of Israeli researchers in the field of instructional technologies and to the positioning of the Open University of Israel as a leading organization in the study and implementation of learning technologies. About 500 researchers from most of the academic institutions in Israel and from many organizations and companies participated in the conference each year for the past four years.

The purpose of the IJELLO special series of Chais Conference best papers is to further enhance the Chais conference international impact and to encourage submission of high quality papers to the conference. The Informing Science Institute (ISI) is a natural partner for this initiative because it draws together people who teach, research, and use information technologies to inform clients to share their knowledge with others (http://www.informingscience.org/). The informing science transdiscipline studies the informing process, defined as providing a specific clientele with information in a form, format, and schedule that maximizes its effectiveness (Cohen, 1999, 2009; Gill \& Cohen, 2009). Instructional technologies are a certain type of information technologies, which are aimed at providing students and other learners with information and tools to enhance their learning. Within the ISI journals, the Interdisciplinary Journal of E-Learning and Learning Objects publishes high quality articles on theory, practice, innovation, and research that cover all aspects of E-learning and Learning Objects (http://www.ijello.org).

\section{Chais Conference 2009 Best Papers}

About 80 short papers were submitted to Chais conference 2009, and, after undergoing a blind peer-review process, 47 of them were presented at the conference and included in the proceedings volume (Eshet-Alkalai, Caspi, Eden, Geri, \& Yair, 2009), as well as 11 posters. This inaugural issue of the IJELLO Special Series of Chais Conference Best Papers includes 13 of the most outstanding Chais Conference papers, which were extended and modified for publication in IJELLO, and have undergone a full review process by the IJELLO editors and reviewers.

The first paper by Yigal Rosen and Rikki Rimor ("Using collaborative database to enhance students' knowledge construction ") examines the effectiveness of technologies as mind tools in a collaborative learning environment.

Arnon Hershkovitz and Rafi Nachmias ("Learning about online learning processes and students' motivation with Web usage mining") develop an assessment tool for measuring motivation of online learners. 
David Pundak, Orit Hershkowitz, Miri Shaham, and Rivka Wiser-Biton ("Instructors' attitudes toward active learning") analyze institutional aspects of integrating technologies in higher education.

Collaboration and social interaction on the net was studied by Ina blau, Nili Mor and Tami Neuthal ("Open the windows of communication: Promoting interpersonal and group interactions using blogs in higher education") who found that educational blogs improve online learning by creating a peer dialogue.

Daphne Raban and Dorit Geifman ("Designing online information aggregation and prediction markets for MBA courses") study cognitive aspects of learning with technologies and use online simulations to enhance MBA students' learning.

Oren Zukerman, Ina Blau and Andrés Monroy-Hernández ("Children's participation patterns in online communities") analyze the motivation and participation patterns of children aged 9-17 in online communities.

The following five papers study various aspects of technology integration in teaching and learning. The paper by Michael Beaudoin, Gila Kurtz, and Sigal Eden ("Experiences and opinions of e-learners: What works, what are the challenges, and what competencies ensure successful online learning ") takes the learners' perspective, and compares students from the United States, Israel, Japan and Mexico. Three of the other four papers examine the instructors' perspective, and one paper deals with learning in business environments.

Eva Guterman, Yael Alberton, Relly Brickner, and Ronit Sagi ("Course coordinators' beliefs, attitudes and motivation and its relation to self-reported changes in technology integration at the Open University of Israel") analyze enhancing and inhibiting factors of instructors' decision to implement instructional technologies in their courses.

Tamar Shamir-Inbal, Jacob Dayan, and Yael Kali ("Assimilating online technologies into school culture") examine cultural aspects of technology implementation by teachers in three elementary schools.

Eyal Sela and Yesha Sivan ("Enterprise e-learning success factors: An analysis of practitioners' perspective") identify success factors for enterprise e-learning based on 12 semi-structured interviews conducted with e-learning project leaders in 11 medium-size companies.

Orit Naor-Elaiza and Nitza Geri ("Not as easy as e-mail: Tutors' perspective of an online assignment submission system") analyze the factors affecting continued use of an online submission system by instructors.

The last two papers deal with innovative technologies in the service of learning. Ruti Gafni ("Quality metrics for PDA-based m-learning information systems") examines the quality problems of PDA-based information systems in the context of mobile learning.

Yair Levy and Michelle Ramim ("Initial development of a learners' Ratified Acceptance of Multi-biometrics Intentions Model (RAMIM)") address the issue of user authentication, which is a major concern in e-learning environments.

The papers cover most of the themes included in the Chais conference proceedings. The themes that are not represented here are: Technologies in the service of people with special needs; Principles in the design and representation of visual information; Technologies integration in teachers' training; Open educational resources. 


\section{Conclusion and Acknowledgements}

We hope this inaugural issue of IJELLO special series of Chais conference best papers will be of interest to the readers and will encourage future innovative and synergetic instructional technologies research. We look forward to the IJELLO next issue of the best papers of Chais conference 2010, which will be held in February 10, 2010, at the Open University of Israel campus in Raanana, Israel.

We would like to express our gratitude to Alex Koohang, the Editor-in-Chief of the Interdisciplinary Journal of E-Learning and Learning Objects, for his enthusiastic support and encouragement and for conducting this editorial effort.

Special thanks to Eli Cohen and Betty Boyd of the Informing Science Institute for enabling this initiative and for the publishing work.

Thanks to all the contributing authors and reviewers for their excellent work. Finally, we would like to thank the community of Israeli instructional technologies researchers and practitioners for participating in Chais conferences and contributing to the development of this important field.

\section{References}

Cohen, E. (1999). Reconceptualizing information systems as a field of the transdiscipline informing science: From ugly duckling to swan, Journal of Computing and Information Technology, 7(3), 213-219.

Cohen, E. (2009). A philosophy of informing science. Informing Science: the International Journal of an Emerging Transdiscipline, 12, 1-15. Retrieved from http://inform.nu/Articles/Vol12/ISJv12p001015Cohen399.pdf

Eshet-Alkalai, Y., Caspi, A., Eden, S., Geri, N., \& Yair, Y. (Eds.) (2009). Proceedings of the Chais Conference on Instructional Technologies Research 2009: Learning in the Technological Era. Raanana: The Open University of Israel.

Gill, T. G., \& Cohen, E. (Eds.). (2009). Foundations of informing science, 1999-2008. Santa Rosa, CA: Informing Sciences Press.

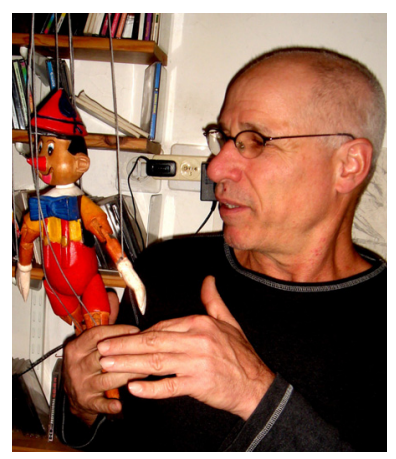

\section{Biographies}

Yoram Eshet-Alkalai is a faculty member at the Open University of Israel, Department of Education \& Psychology. He is the Coordinator of the M.A. program in educational technology and the Head of the Chais Research Center for the Integration of Technology in Education in the Open University. He holds a B.A. in Archeology (Hebrew University), M.Sc. in Geology (Hebrew University) and Ph.D. in Earth \& Environmental Sciences (City University of NY). For a decade, he was the Head of the Instructional Design Program in the Tel Hai Academic College, and a senior researcher in the Geological Survey of Israel. He has 15 years experience in developing technology-based instructional solutions for educational systems in Israel and the USA. In this capacity, he was involved in the design of hundreds of simulations, data-bases, tutorials and large-scale curriculum integration projects. His major research and publications interests focus on cognitive aspects of working with digital technologies, digital games and design principles of computerbased learning environments. Personal site: http://www.openu.ac.il/Personal sites/yorameshet.html 


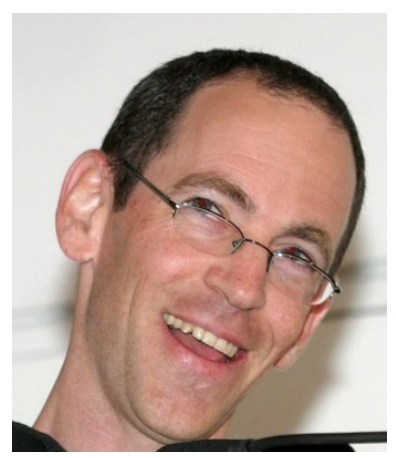

Avner Caspi is a faculty member at the Open University of Israel, Department of Education \& Psychology. He holds a B.A. in Behavioral Sciences (Tel-Aviv Yaffo Academic College), and Ph.D. in Cognitive Psychology (Tel Aviv University). His major research and publications interests focus on social aspects of communication technologies, mainly in the area of learning and instruction. Personal site: http://www.openu.ac.il/Personal_sites/avner-caspi.html

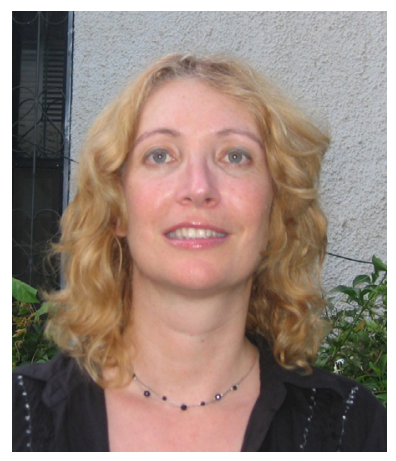

Sigal Eden is a fellow researcher and a member of the Chais Research Centre, the Open University of Israel, and a lecturer of Bar Ilan University, School of Education. She holds a B.A. in Education for Students with Hearing Impairment from Tel-Aviv University, an M.A. and Ph.D. in Educational Technologies from Bar-Ilan University. Her research interests and publications focus on various aspects of working with digital environments, especially the enhancement of cognitive and linguistic aspects among people with special needs. Personal site: http://www.openu.ac.il/research_center_eng/Sigal_Eden_card_E.html

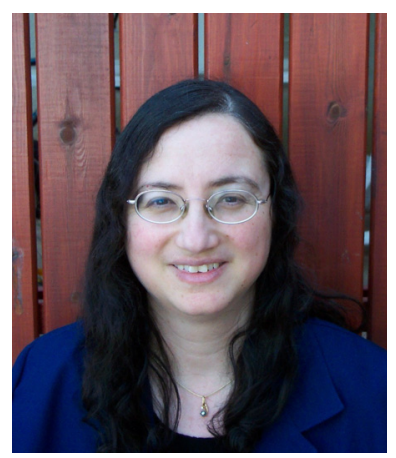

Nitza Geri is Head of the Department of Management and Economics, the Open University of Israel and a member of the Chais Research Center for the Integration of Technology in Education. She holds a B.A. in Accounting and Economics, an M.Sc. in Management Sciences and a Ph.D. in Technology and Information Systems Management from Tel-Aviv University. Nitza is a CPA (Israel) and prior to her academic career she had over 12 years of business experience. Her research interests and publications focus on various aspects of the value of information, and information systems adoption and implementation, including strategic information systems, e-business, value creation and the Theory of Constraints, managerial aspects of e-learning systems adoption and use. Personal site: http://www.openu.ac.il/Personal sites/nitza-geri.html

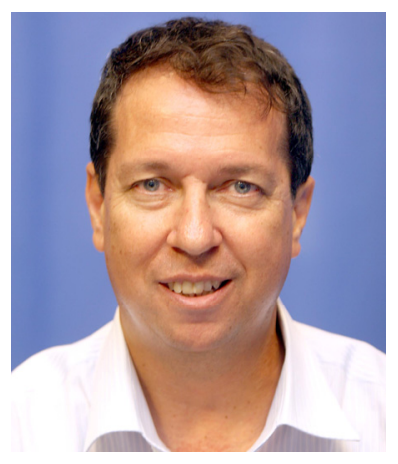

Yoav Yair is a faculty member at the Open University, in the Department of Life and Natural Sciences. He is an expert on educational technology, having worked as software designer and educational program developer at the Centre for Educational Technology (CET) in Tel-Aviv for 15 years. His main interests in this field are scientific visualization and desktop virtual reality. He also wrote 4 textbooks for the K-12 Israeli education system and was a chief software designer of several educational software and websites. At the Open University of Israel, since 2004 Prof. Yair heads the Centre for Technology in Distance Education (SHOAM), tasked with developing, testing, disseminating, and evaluating learning technologies for usage in distance education. In this capacity he is responsible for introducing new technologies into the Open University, with 
emphasis on the academic usage of the OPUS Hebrew-based learning management system, of video broadcasts and synchronous voice-over-IP systems, as well as collaborative tools such as Wikis. Prof. Yair leads the Open Courseware project at the Open University of Israel, with a new initiative to open complete e-books and audio-books on-line for free usage by the general public. Prof. Yair published numerous papers in atmospheric sciences and on the usage of technology in science and distance education. He now leads new projects in mobile e-books for academic courses. Prof. Yair is an atmospheric and space physicist and leads a research team for studying thunderstorms, lightning and their effects on the atmosphere. Another field of research is science education with emphasis on Astronomy and the Earth Sciences. Personal site:

http://www.openu.ac.il/Personal_sites/yoav-yair.html 